\title{
Academics abroad: U.S. librarians visit the People's Republic of China
}

\author{
By Sharon Rogers \\ Library Director \\ George Washington University
}

\begin{abstract}
ACRL members compare notes with their colleagues on the Mainland.
\end{abstract}

$\mathbf{I}_{1}$ In April 1985, sixty-five U.S. librarians visited the People's Republic of China. The tour was sponsored by the China Society of Library Science and arranged by the China Association for Science and Technology. Members of the group represented academic, public, special and school libraries, and library education. Co-leaders of the delegation were Robert D. Stueart, dean of the Graduate School of Library and Information Science at Simmons College, and Margo Crist, of the Central Massachusetts Regional Library System. Separated into two groups, based on an emphasis in public or academic libraries, the delegation traveled together in Beijing and Xian, and then the academic librarians traveled to Chengdu and Shanghai, while the public librarians visited Nanjing, Wuhan, and Guangzhou.

I asked several of the ACRL members on the trip to write some of their reactions to Chinese libraries for this report. They wrote far more than I have space for here, but I have selected paragraphs from each set of comments to convey impressions gained from it. I can only beg the forgiveness of my colleagues for risking the omission of some of their finest prose or favorite impressions.

While not all members of the delegation visited exactly the same academic libraries, the schedule for the academic librarians included the following libraries: Beijing (Beijing University, Renmin Uni- versity, Historical Archives); Xi'an (Shaanxi Provincial Library, Northwestern University, Shaanxi Teachers University); Chengdu (Sichuan Institute of Scientific and Technical Information, Sichuan Library, Chengdu Institute of Telecommunications Engineering, Sichuan University); Shanghai (Shanghai Public Library, East China Normal University, Shanghai Institute for Information Research, Jiaotang University).--Sharon J. Rogers, George Washington University.

In Shanghai one afternoon, after the formal presentations, several graduate library school students came up to me to discuss library preservation and conservation. Three of them were graduate library school students, enrolled in the 3-year, postbaccalaureate program. Upon receipt of their master's degrees in 1987, the three said that they would likely be assigned to the teaching faculty of library schools in China. The need for teachers in China is so great that as soon as advanced students are graduated, they are immediately posted to faculty positions somewhere in China.

I also attended the Shanghai Bookfair. Several rooms in a large official-style Soviet-built exposition building were filled with tables and chairs, and along the walls, bookstack after bookstack, seven feet high, were publishers' books. The books came from nearly 100 mainly English language 
publishers from all over the world. Subjects covered were mainly technical and scientific, agriculture, pure sciences, mathematics, engineering, and computers. Added to these were standard reference books.

The place was mobbed. There were young Chinese everywhere reading and thumbing through the books intensely. I was told by one exhibitor that

\section{An abacus was used to calculate charges on a copy machine.}

when the fair opened at 9 a.m., all the free literature that the publishers had put out was simply consumed by the vast numbers who came to the Fair.-Stephen Ferguson, Princeton University.

Women in librarianship in China. At most libraries we visited one woman generally was at the assistant director level, but none of the directors were women. In group discussions they were generally less likely to ask questions or offer comments. When touring libraries (reading rooms, stacks, circulation, cataloging) women appeared to be the majority of staff. It seems that they do the "work" of keeping the libraries open and running but are rarely in positions of authority.

Introductions to libraries always included many statistics. Reading rooms and entrance rooms of libraries generally had maps of the library and other general user aids. Faculty and students had separate reading rooms and stacks were closed. Reading rooms were full to overflowing.-Barbara Ford, Trinity University.

Academic and scientific research libraries in China are actively developing automation and networking, but cataloging and classification systems pose challenging problems. While most catalogs are classified, there is not a single classification system to use as a basis for standardizing automated records and union cards. There are two major systems, the Chinese Library Classification System, and the Chinese Academic Library System. The National Library in Beijing supplies both systems for its present union catalog cards (before 1965, LC was used), but when the library records are fully automated, only the Chinese Library Classification System will be used because, according to the National Library, about $80 \%$ of libraries presently use this system. The Chinese Library Classification is published in a single volume and uses alphanumeric codes. It is criticized by librarians who prefer the Chinese Academic Library System as being suitable for generalized collections but not adequate for specialized collections, especially in scientific libraries.

The China Library Society, as part of its 1st Council (1979-83), sponsored a National Seminar on Classification and Subject Cataloging, and the 2nd Council (1983-) has a Section of Classification and Subject Cataloging as one of twelve study groups of its Academic Committee for Research. One result of these seminars has been the development and teaching of classes on the cataloging of Chinese materials, attended by most cataloging supervisors in Beijing. An estimated 1,500 cataloging staff members have been trained since September 1984.

The National Library in Beijing has long-term plans for the creation and distribution of an online national database in Chinese and in the original language for foreign materials. ISBD and AACR2 will be used for all languages. It will use MARC format and include romanized and cyrillic characters. Both tapes and cards will be produced and distributed nationally. Access points will include LC class number, ISBN, and LC Subject Headings. It is estimated that initial automation efforts will begin about 1990 .

Individual libraries have a wide variety of equipment and practices ranging from the hand stencilled one-at-a-time duplication of catalog cards to the electronic Chinese CRT at the National Library which feeds in information by Optical Charcter Recognition. Instead of typing at a Western-style keyboard, the operator touches a light pen to the character which then displays on the screen. - Sheryl Horner, University of Colorado.

Most of us were surprised by the extent to which English was understood and spoken. This made our discussions easy and productive. The ability to break into small groups and discuss specific topics was an unexpected surprise. In these discussions we discovered that our Chinese colleagues not only knew what questions to ask but they were as current on many trends in librarianship as we were. The real problem they have is the lack of an infrastructure to support what they wish to accomplish. There is neither a transportation system that can quickly move materials from one city to another nor a telecommuncations system that can meet their needs. - Michael Kathman, St. Johns University.

The language barrier, however, slows down indepth gathering of information. The Chinese are used to the slow pace of formal meetings with foreigners. They have lived with the protocol of speech, followed by translation, in their dealings with traders, for a long time. Americans find the process ponderous.

As a delegation, we were often unaware of ar- 


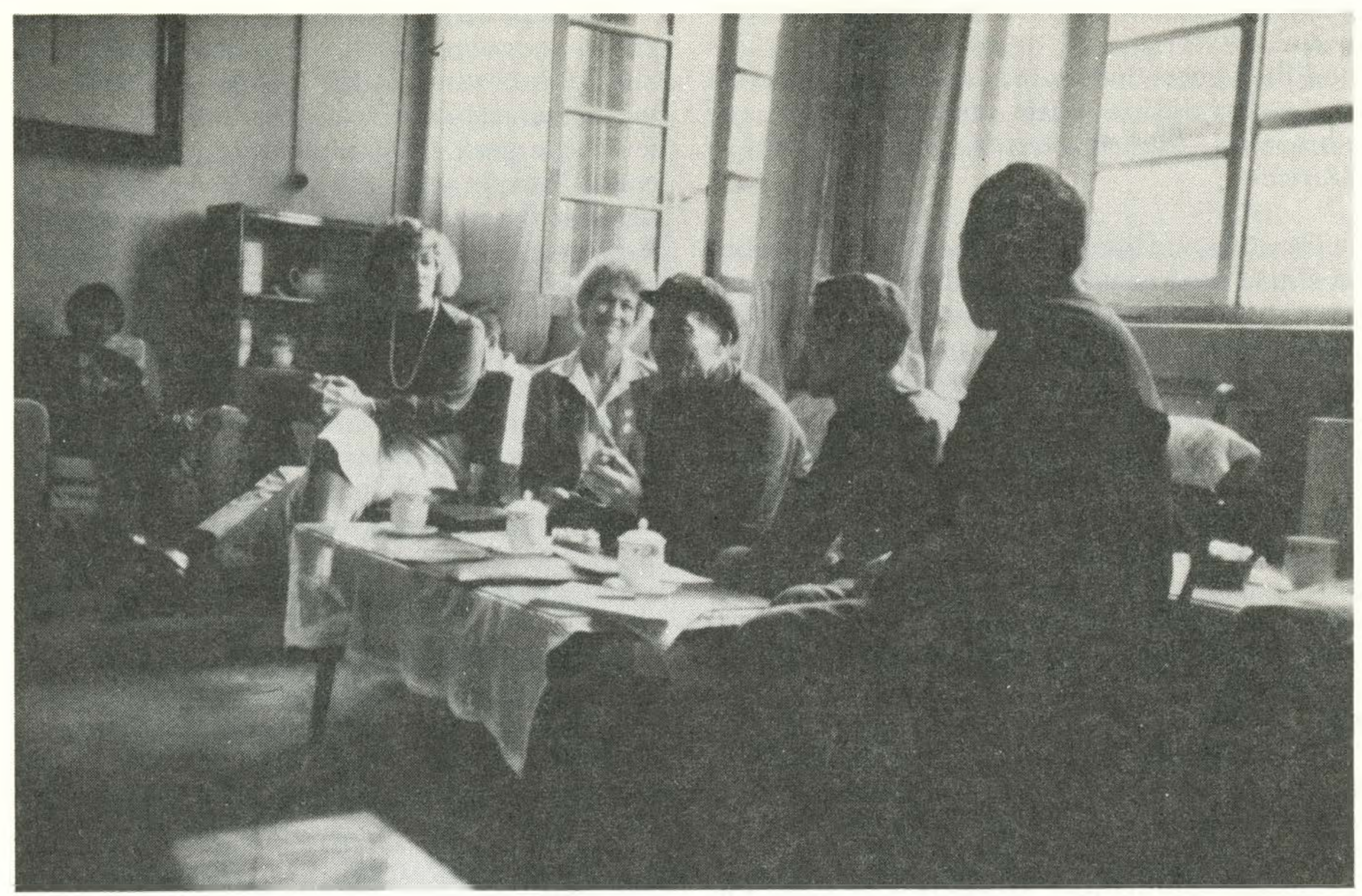

Cr: Sharon Rogers

The director of Northwestern University Library at Xi'an, speaks to the American delegation, which included Beth Shapiro and Margo Crist (center left and right).

rangements and partnerships already developed with American and British libraries and foundations. Only by talking to individual librarians and by chance meetings with other foreign visitors did we find that independent, uncoordinated, and often enterprising, exchange is taking place.Noelene Martin, Pennsylvania State University.

Special visit to the Academica Sinica Regional Library in Chengdu. The Academica Sinica is organized similarly to the British model of a central government scientific research organization. The Chengdu regional library serves research institutes in areas as diverse as geography and computer science. The emphasis is on pure research, but they also work on applied research projects, such as water irrigation.

I had been invited to speak on multidisciplinary research, drawn from my experience with the Center for Environmental Management at Tufts University. This was an atypical request because the division between disciplines seems to be basic, not only to the Chinese library system, but to education and scientific research. Explanations suggesting seeking joint solutions to different problems seem to be alien to the listeners.

A new library is just completing construction. Although the stacks are still divided into general subject categories, they are all open access and the usual multiple circulation desks seemed absent. The real surprises were a standard Western-style auditorium and a single reference bibliography area where there is provision for reference librarians.-Murray Martin, Tufts University, and Noelene Martin, Pennsylvania State University.

Certain assumptions made upon entering an American library-a place to sit and a copy machine-cannot be made in many of China's major libraries. In many libraries we observed a system of table numbers which assigned spaces to users for a fixed period of time. In Sichuan University Library we saw a copy center with 6 machines, with a window counter opening on a hallway. Copies were about 2 cents each. It was humorous but significant to see an abacus being used to calculate the charges for a Sharp copy machine.-John Mayeski, Kearney State College.

The old and inadequate buildings at most universities contrasted with the new libraries. For instance, the Chengdu Institute for Telecommunications Engineering has a good physical plant and a large scientific collection arranged in separate collections: reference (including indexes), periodicals (Chinese, foreign), monographs, technical reports, patents, technical catalogs, and newsletters. In all libraries the importance of their strong Englishlanguage collection was clear. Online searching is rare, but it is possible to request a search by mail to Beijing. The library science students in the rapidly increasing library science departments are eager and inquisitive, certainly aware of reference and 
bibliographic instruction issues. The Chinese professional librarians are strongly interested in IFLA and their opportunities for exchange of materials and information with other libraries and librarians. - Robert Merikangas, University of Maryland.

Libraries and librarians in the People's Republic of China are knowledgeable about U.S. Government publications. The National Library in Beijing receives full depository shipments which include the Monthly Catalog and the NTIS Government Reports Announcement and Index. This collection is kept separate from other material and is largely received in microfiche. When asked about the availability of this information on interlibrary loan to other libraries in the country, responses varied. Some librarians felt it was readily available; others did not know. Several libraries know and use NTIS materials._Lois Mills, Northern Illinois University.

For me, the highlights of the trip were the opportunities to visit with the Chinese librarians and students. There seemed to be so few women administrators that the opportunity to get their ideas and viewpoints was limited. Students who spoke English (and wanted to practice it) frequently approached me on the campuses or in the streets to find out what we were doing in China and what we thought of various questions. - Vivian Peterson, Concordia College Library.
Although I tried to bring up topics of reference service and online searching, I found little opportunity to deal with specific questions. It appeared that actual reference service was available in only a few of the many sub-libraries on campuses; in most cases I had the impression that the employee assigned to the room performed a custodial function. However, the interest which the Chinese hosts expressed in bibliographic instruction convinced me that there is a desire to provide reference service, but there is probably not yet a large enough number of librarians trained in reference work to meet the demand for such service, particularly given the distribution of reference materials over such a large number of single-subject reading rooms. - Pat Reisenman, Indiana University.

In many ways the academic libraries of China reminded me of the state of U.S. academic libraries in the late 1950s and early 1960s. Some of the similarities include: initial interest in automation, but only the beginnings of any automated systems and, as in the U.S., these are developing independently with little knowledge of others' activities or efforts to coordinate; more concern with collections than services; controversy over the "correct" classification system; extensive construction of library buildings; concern with preservation of materials. In the differences lie the advantages for the Chinese librarians: the Chinese can see what the U.S. and Europe has done, learn from our mistakes and skip several generations of hardware and software.

\section{Stocked Any Language Courses Lately?}

A growing number of libraries are acquiring our self-instructional book / cassette courses for use by their patrons. We offer comprehensive courses in:

$\begin{array}{cc}\text { Afrikaans } & \text { French } \\ \text { Amharic } & \text { German } \\ \text { Arabic } & \text { Greek } \\ \text { Bulgarian } & \text { Haitian Creole } \\ \text { Cambodian } & \text { Hausa } \\ \text { Cantonese } & \text { Hebrew } \\ \text { Danish } & \text { Hindi } \\ \text { Dutch } & \text { Hungarian } \\ \text { English } & \text { Indonesian } \\ \text { Finnish } & \text { Italian }\end{array}$

Japanese
Korean
Mandarin
Norwegian
Persian
Polish
Portuguese
Russian
Serbo-Croatian
Spanish

Swahili

Swedish

Tagalog

Thai

Turkish

Twi

Urdu

Vietnamese

Yoruba

Zulu

Free 32-page catalog available from:

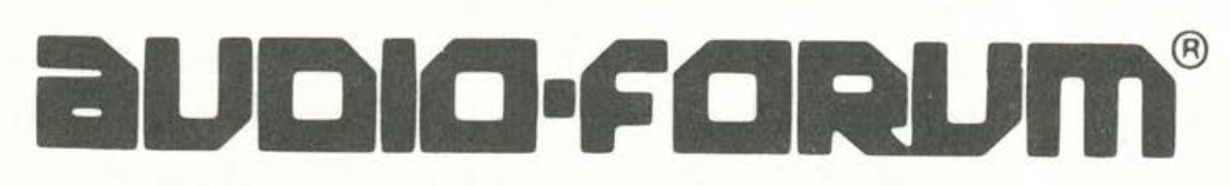

Room L61, 96 Broad Street, Guilford, СT 06437 (203) 453-9794 
What can ACRL and U.S. librarians do? Provide frequent and specific invitations to leading Chinese librarians to visit conferences and U.S. libraries and provide expertise to a long-term cooperation project through: a) sending experts; b) working with the Chinese to develop their own plans-and not repeat our mistakes; c) culminating a 5- or 10-year project with a conference with U.S. and Chinese leaders working together to see what can be achieved.-Trish Ridgeway, Winthrop College.

Reference and collection development activities in Chinese academic libraries are not as yet well developed. It is not apparent to one entering the lobby of a Chinese academic library that one is in a library! Card catalogs, service desks, and reading rooms are located away from major first floor traffic areas.

One outstanding feature of Chinese libraries is their commitment to the subject divisional approach to all library services. Most American li- braries abandoned this type of functional arrangement about 20 years ago due to fiscal constraints. Instead, strong central services have been developed in the U.S., allowing more opportunities for subject specialization in collection development and reference.

Visits to Northwestern University in Xi'an and Sichuan University in Chengdu gave me the opportunity to meet with two Michigan State University faculty who are teaching English in China this year. In contrast to what the library staff members at these institutions told the delegation, both of these faculty members told me that it is extremely difficult for their students to get access to English language requested materials - they were frequently "unavailable." I was told that the Foreign Language Department faculty at Northwestern have begun a departmental English language reading room for their students because it seems the role of the librarians has been to keep the students away from the English language books. - Beth Shapiro, Michigan State University.

\section{Academic or Research Librarian of the Year Award}

The Association of College and Research Libraries invites nominations for the Academic or Research Librarian of the Year Award, presented jointly by ACRL and the Baker \& Taylor Company. Anyone wishing to submit nominations should send the form on the following page to ACRL/ALA, 50 E. Huron St., Chicago, IL 606112795.

Recipients of the award since its inception in 1978 have been Keyes D. Metcalf and Robert B. Downs (1978); Henriette D. Avram and Frederick G. Kilgour (1979); Evan I. Farber (1980); Beverly P. Lynch (1981); William Budington (1982); Richard M. Dougherty (1983); Richard D. Johnson (1984); and Jessie Carney Smith (1985).

The Award Committee selects persons to receive the award in accordance with the following guidelines:

Purpose: To recognize an individual member of the library profession who is making an outstanding national or international contribution to academic or research librarianship and library development.

Criteria: Individuals nominated should have demonstrated achievements in such areas as:

1. Service to the organized profession through ACRL and related organizations.

2. Significant and influential research on academic or research library service.

3. Publication of a body of scholarly and/or theoretical writing contributing to academic or research library development.

4. Planning and implementing a library program of such exemplary quality that it has served as a model for others.
The nominee does not have to meet all of the above criteria.

Rules: The award shall be made each year at a time and place to be determined by the ACRL Board of Directors. Announcement of the award shall be made by the ACRL president at a time and place to be determined by the ACRL Board of Directors. If, in the opinion of the Award Committee, no worthy candidate is nominated in a given year, the award will not be presented that year.

Nominations: Nominations for the award must be returned to the chair of the Academic/Research Librarian of the Year Award Committee and must be postmarked no later than December 1, 1985. Nominations must be submitted in quintuplicate and should be accompanied by a statement of supporting reasons and a copy of the nominee's resume. Please do not solicit supporting letters seconding your nomination. Such letters will not be considered in the Award Committee's decision.

Nature of the award: The Academic or Research Librarian of the Year Award shall consist of $\$ 3,000$ and an appropriate citation.

The Award Committee for 1985 consists of the following persons: Charles B. Osburn (chair), Librarian, University of Cincinnati, University and Woodside, Cincinnati, OH 45221-0033; Dale B. Canelas, Director, University of Florida Libraries, 210 Library West, Gainesville, FL 32611; James F. McCoy, 66E Bishop's Gate, Guilderland, NY 12084; Jean Pelletiere, 2167 Stuyvesant Street, Schenectady, NY 12309; Shelley E. Phipps, 4001 S. Jamie Dr., Tucson, AZ 95746; and Ann E. Prentice, Director, GSLIS, University of Tennessee, 804 Volunteer Blvd., Knoxville, TN 37996. 


\section{The Off-campus Library Services Conference II}

More than one hundred librarians and educators gathered at the Knoxville Hilton on April 18-19, 1985, for the Off-campus Library Services Conference II, sponsored by Central Michigan University Libraries and the Institute for Personal and Career Development. Continuing the dialogue that began at an earlier conference held in St. Louis in 1983, participants representing academic institutions from thirty-three states, the District of Columbia, Canada, and England were joined by U.S. military education services officers.

The conference brought together for the first time at the international level the librarians, faculty, and administrators who must work together to develop successful library programs for the distant learner. The primary objective of the conference was to provide a forum where practitioners could gather to exchange relevant ideas, concerns, perspectives, and research.

The keynote address was presented by Barton $\mathrm{M}$. Lessin, assistant director for library off-campus and administrative services at Central Michigan University. In setting the tone for the conference, Lessin's remarks concentrated on the constituencies involved with off-campus library services and challenges which will be faced by those services in the coming years.

The conference highlighted the speeches of four distinguished educators whose featured discussions centered on the role of the library in the context of accreditation, licensure, off-campus/off-duty military academic programs, and the impact caused by off-campus academic programs. These speakers were: Bruce N. Chaloux, coordinator of institutional approval and academic projects for the Virginia Council of Higher Education; Jack Allen, associate executive director for the Commission on
Colleges of the Southern Association of Colleges and Schools; Frances Kelly, head of the U.S. Navy Education Services Section; and Darrell Jenkins, director of library services at Southern Illinois University at Carbondale.

The conference theme, "Current PracticesFuture Challenges," was also explored through twenty paper sessions. Topics covered in the concurrent paper sessions included: case studies of specific ongoing library services; bibliographic instruction; accreditation processes; licensure practices; off-duty military academic programs and library services; remote delivery; support for graduate education; the view from an impacted library; the adequacy of vicinity libraries for external degree programs; a comparison of on-campus and off-campus library use and preferences; reading as a measure of academic standards on and off campus; and microfiche and telephone accessible catalogs.

Linda L. Bennett of Oberlin, Louisiana, and the Louisiana State University School of Library and Information Science, was the recipient of the conference scholarship which was offered to library school students nationwide to encourage their interest and research in off-campus library services. Her paper proposed specific methods of cooperation among academic and state libraries, networks, and local public libraries.

Persons interested in receiving information about this conference or about the opportunities to plan and participate in the next conference scheduled for October 1986 are invited to contact Barton M. Lessin, Assistant Director of Libraries, 206 Park Library, Central Michigan University, Mount Pleasant, MI 48858; (517) 774-6419.

I nominate

(name and present address)

(Please list achievements of your nominee on a separate sheet.)

Nominated by

Address

Please return no later than December 1, 1985, to:

Academic or Research Librarian Award

Association of College and Research Libraries, ALA

50 East Huron Street

Chicago, IL 60611-2795 


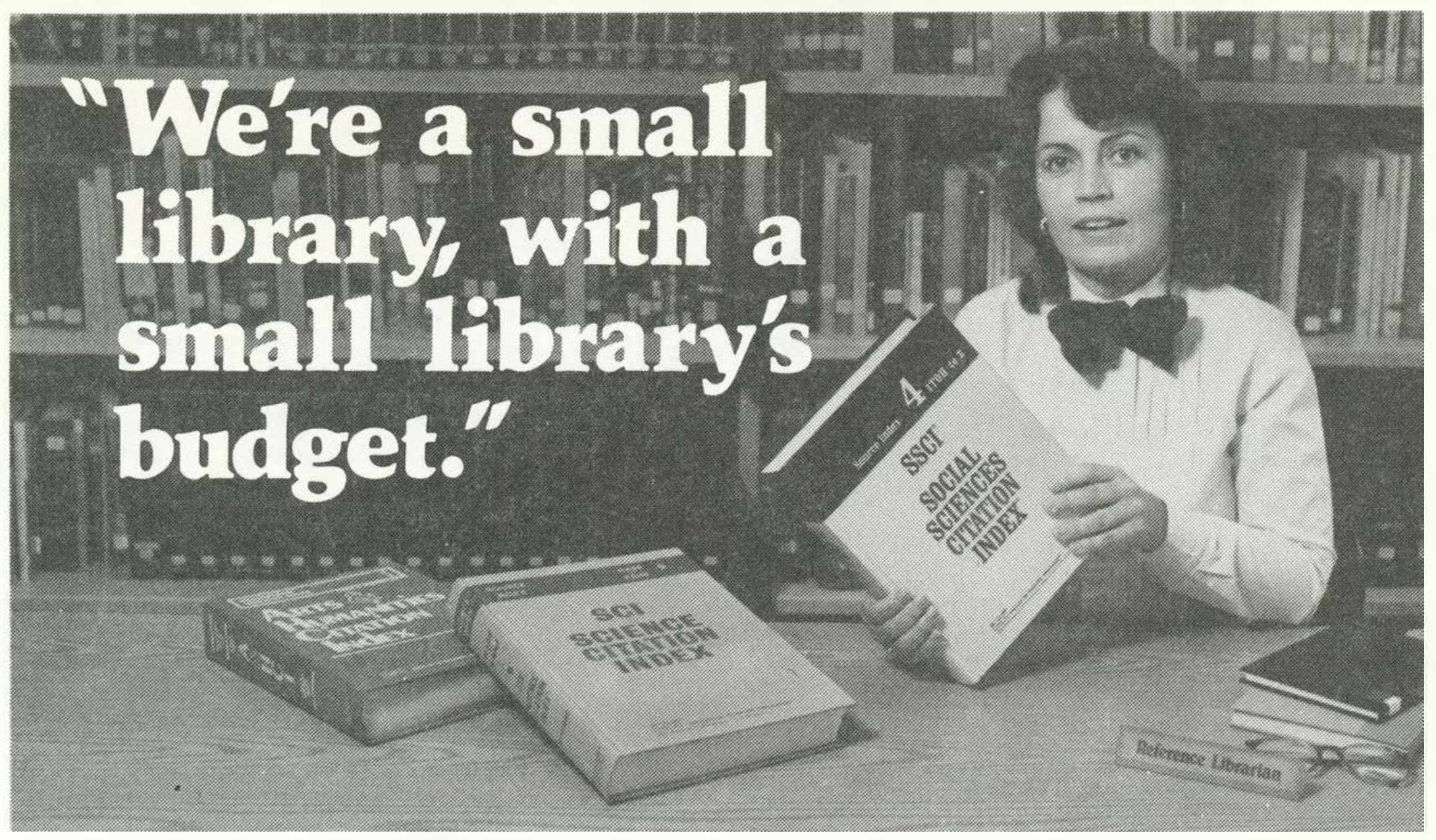

"But thanks to the ISI ${ }^{\circledR}$ Grant Program, we can afford the big library coverage and the currency of the Science Citation Index ${ }^{\circledR}$, the Social Sciences Citation Index ${ }^{\circledR}$, and the Arts $\mathcal{E}$ Humanities Citation Index ${ }^{\mathrm{TM}}$."

For over ten years, the ISI Grant Program has been helping "small" libraries just like yours purchase ISI's major indexes at significant discounts. Today, libraries at California State College at Chico, Massachusetts General Hospital, Middlebury College, the Minneapolis Public Library, Portsmouth Polytechnic in England, and Mexico's Universidad Nacional Autonoma de Mexico are just a few of the institutions that own ISI indexes as a direct result of these discounts. Thanks to the ISI Grant Program, these libraries can now afford the thorough, precise literature search capabilities of the Science Citation Index, the Social Sciences Citation Index, and the Arts \& Humanities Citation Index.

Isn't it time your library discovered the ISI Grant Program? To find out how your library can qualify, just call our Customer Services Department at 800-523-1850, extension 1371. In Pennsylvania, call collect 215-386-0100, extension 1371. We'll send you a free, no-obligation evaluation form that will help us determine your library's eligibility.

\section{号邑 ${ }^{\circledR}$ Institute for Scientific Information ${ }^{\circledR}$}

